\title{
Peran Lembaga Amil Zakat dalam Meningkatkan Kesejahteraan Keluarga Janda Miskin Melalui Program Kampung Mandiri di Laznas Yatim Mandiri Kudus
}

\author{
Firda Ramadhanti, H. Fu'ad Riyadi \\ Institut Agama Islam Negeri Kudus \\ firdarama16@gmail.com
}

\begin{abstract}
The purpose of this research is to analyze the role of the Amil Zakat Institution (LAZ) in the economic sector to improve the welfare of poor widowed families, namely through the economic empowerment program of the Kampung Mandiri National Amil Zakat Institute (LAZNAS) Yatim Mandiri, Kudus Branch located in Cangkring B Village, Karanganyar District, Regency. Demak. The results showed that the LAZNAS Yatim Mandiri Kudus Branch program in the formation of the Kampung Mandiri program, namely first, planning the formation of the Kampung Mandiri program in Cangkring B Village Karanganyar Demak to the implementation of the program, with the business being managed is fried onions with the branding "Guemez Onions". Second, the distribution of funds for the Kampung Mandiri program is budgeted at Rp. 128,590,000 for capital and program facilities and infrastructure. Third, monitoring the Kampung Mandiri program. The role of the Kampung Mandiri program for poor widows is first, to provide knowledge of entrepreneurship and Islam. Second, increase entrepreneurial skills. Third, increase income. The role of LAZNAS Yatim Mandiri, Kudus Branch is still not optimal in improving the welfare of poor widow families because the income earned from working wages when the production of fried onions is of little value and the profits from sales cannot be used directly by widows because they are still collected and stored first. The Kampung Mandiri program has been supported by the existence of village approval, grants for program activities, and business capital from LAZNAS Yatim Mandiri Kudus Branch. Meanwhile, the obstacles experienced are the slow rate of development, the production process is not yet optimal, the lack of cohesiveness of the members of Kampung Mandiri, and the marketing of products that are not optimal.
\end{abstract}

Keywords : Amil Zakat Institution, Poor Widows, Independent Village Program

\section{Latar Belakang}

Kemiskinan sebagai salah satu fenomena sosial yang sulit untuk di tuntaskan karena ketidak seimbangan antara laju pertumbuhan 
pendudukan yang cepat dengan pertumbuhan ekonomi yang memadahi. Sehingga dengan hal ini kaum yang lemah akan kalah dengan kaum yang lebih tinggi untuk memenuhi perekonomiannya. Rendahnya kualitas yang dimiliki manusia juga merupakan penyebab timbulnya permasalahan kemiskinan.

Salah satu cara untuk membantu mengentaskan kemiskinan menurut syariat Islam adalah dengan menumbuhkan zakat. Selain berdimensi spiritual, zakat juga dapat berfungsi pada dimensi sosial dan ekonomi. Zakat salah satu dari rukun Islam yang membentuk Islam termasuk dalam ibadah maaliah ijtima'iyyah memiliki posisi yang strategis untuk membangun kesejahteraan perekonomian masyarakat. Fungsi zakat secara vertikal adalah untuk beribadah kepada Allah (hablumminallah) dan wujud ibadah bersifat secara horizontal (hablumminannas). ${ }^{1}$

Fungsi zakat untuk membantu mengentaskan kemiskinan tergantung pada peran pengelola zakat yang mampu mengelola zakat dengan profesional. Salah satu inovasi dari pengembangan pengelolaan zakat yaitu zakat produktif dimana zakat dapat disalurkan kepada mustahik sebagai bantuan modal bagi usaha kecil. ${ }^{2}$ Dengan bantuan dari zakat ini diharapkan lebih efektif lagi dalam meningkatkan perubahan yang bersifat ekonomis bagi kelompok yang kurang mampu.

Yatim Mandiri merupakan Lembaga Amil Zakat Nasional (LAZNAS) yang ikut berkontribusi dalam melakukan pengelolaan zakat, infak, dan sedekah (ZIS) di Indonesia. Selama ini sudah banyak keberhasilan dan pencapaian yang diperoleh oleh LAZNAS Yatim Mandiri, baik dalam hal pengelolaan, penyaluran, dan pemberdayaannya. Yang menjadi penerima manfaat atau sasaran utama LAZNAS Yatim Mandiri adalah anak yatim yang kurang mampu dan dhuafa. Dalam pengelolaannya LAZNAS Yatim Mandiri dituntut untuk profesional sehingga menghasilkan daya guna yang bermanfaat untuk meningkatkan kesejahteraan keluarga anak-anak yatim dhuafa. Melalui programprogram unggulan yang dibentuk oleh LAZNAS Yatim Mandiri dari hasil pengelolaan zakat baik dalam bidang kesehatan, pendidikan, ekonomi dan sosial hal ini sudah mampu merangkul banyak anak yatim dhuafa yang seterusnya akan menjadi anak binaan LAZNAS Yatim Mandiri.

Selain tujuan utamanya untuk membantu anak-anak yatim dhufa dalam meningkatkan kualitas hidupnya, LAZNAS Yatim Mandiri juga

${ }^{1}$ Nurul Huda, dkk., Zakat Perspektif Mikro-Makro Pendekatan Riset. Jakarta: Prenada Media Group, 2015, 5.

${ }^{2}$ Mulkan Syahriza; Pangeran Harahap; Zainul Fuad (2019), "Analisis Efektifitas Distribusi Zakat Produktif dalam Meningkatkan Kesejahteraan Mustahik (Studi Kantor Cabang Rumah Zakat Sumatera Utara)", at-Tawassuth, IV (1), 137-159. 
mulai mencoba untuk melakukan pemberdayaan kepada keluarga dari anak-anak yatim yaitu para ibu-ibu yang sudah tidak memiliki suami atau bisa disebut dengan janda. Para ibu-ibu ini dikumpulkan dalam suatu wadah organisasi dibidang usaha yang akan mereka kelola dengan bantuan pemberdayaan ekonomi dari LAZNAS Yatim Mandiri yaitu melalui program Kampung Mandiri.

Pemberdayaan kepada para janda ini guna bermaksud untuk meningkatkan perekonomian mereka sehingga nantinya diharapkan hidup keluarga yatim dhuafa ini akan berubah menjadi lebih sejahtera dan mandiri. Di Kudus sendiri sudah terdapat cabang dari LAZNAS Yatim Mandiri yang juga sudah menjalankan program Kampung Mandiri. Karena itu, penulis ingin mengetahui bagaimana program Kampung Mandiri ini dan bagaimana peran program Kampung Mandiri LAZNAS Yatim Mandiri Cabang Kudus untuk meningkatkan kesejahteraan keluarga janda. Maka penulis dalam karya ilmiah ini ingin menjawab tiga pokok masalah, yaitu: bagaimana program Kampung Mandiri yang ada di LAZNAS Yatim Mandiri Cabang Kudus, bagaimana peran program Kampung Mandiri LAZNAS Yatim Mandiri Cabang Kudus bagi janda miskin di Desa Cangkring B Karanganyar Demak dan apa saja faktor pendukung dan penghambat pelaksanaan program Kampung Mandiri LAZNAS Yatim Mandiri Cabang Kudus.

\section{Kerangka Teori}

\section{Kajian Zakat}

Zakat (zakah) dalam bahasa bermakna "mensucikan", "tumbuh", atau "berkembang". Disebut demikian karena apabila mengeluarkan harta untuk berzakat, maka harta tersebut akan menjadi tumbuh dan mendatangkan berkah yang berlipat ganda lagi serta menjadi lebih baik. ${ }^{3}$ Sedangkan, menurut istilah syara', zakat bermakna mengeluarkan sejumlah harta tertentu untuk diberikan kepada orang-orang yang berhak menerima (mustahik) sesuai ketentuan syariat Islam. Zakat menjadi salah satu rukun Islam yang kelima dan hukumnya wajib dilaksanakan. ${ }^{4}$

Dan menurut Undang-Undang Nomor 23 Tahun 2011 tentang Pengelolaan Zakat bahwa zakat adalah harta yang wajib dikeluarkan oleh seorang muslim atau badan usaha untuk diberikan kepada yang berhak menerimanya sesuai dengan syariat Islam.

3 Mardani, Hukum Islam: Zakat Infak Sedekah dan Wakaf (Konsep Islam Mengentaskan Kemiskinan dan Menyejahterakan Umat) (Bandung: PT Citra Aditya Bakti, 2016), 13-14.

${ }^{4}$ Yusuf Wibisono, Mengelola Zakat Indonesia DIskursus Pengelolaan Zakat Nasional dari Rezim Undang-Undang Nomor 38 Tahun 1999 ke Rezim Undang-Undang Nomor 23 Tahun 2011 (Jakarta: Prenadamedia Group, 2015), 1. 
Setiap orang yang muslim diwajibkan berzakat untuk berbagi kepada sesamanya. Mustahik merupakan sebutan untuk orang yang berhak menerima zakat. Namun tidak semua orang berhak untuk mendapatkan zakat, didalam Al-Qur'an QS. At-Taubah ayat 60 dijelaskan pihak-pihak yang berhak atas zakat berjumlah 8 golongan atau disebut dengan 8 asnaf, meliputi fakir, miskin, amil, muallaf, riqab, gharim , fisabillah, dan ibnu sabil. ${ }^{5}$

Mannan secara umum juga menerangkan fungsi zakat meliputi bidang moral, sosial dan ekonomi, sebagai berikut:

1) Dalam bidang moral, zakat berfungsi megurangi sifat tamak dan serakah pada hati si kaya.

2) Dalam bidang sosial, zakat berfungsi untuk menghilangkan kemiskinan yang ada di masyarakat.

3) Dalam bidang ekonomi, zakat berfungsi mencegah beberapa manusia yang senang menumpuk hartanya dan sebagai sumbangan wajib muslim untuk perbendaharaan negara. ${ }^{6}$

\section{Lembaga Amil Zakat (LAZ)}

Dalam Undang-Undang Nomor 23 Tahun 2011 tentang Pengelolaan Zakat Lembaga Amil Zakat yang selanjutnya disingkat LAZ adalah lembaga yang dibentuk masyarakat dan dikukuhkan pemerintah yang memiliki tugas melakukan pengumpulan, pendistribusian, dan pendayagunaan zakat sesuai dengan ketentuan agama. Pembentukan LAZ sendiri bertujuan untuk membantu BAZNAS dalam melakukan pengelolaan zakat.

LAZ dapat dibentuk pada tingkat Pusat, Provinsi, dan Kabupaten/Kota. Ruang lingkup kerja LAZ tingkat pusat yaitu semua wilayah negara Indonesia. Sedangkan ruang lingkup kerja LAZ tingkat provinsi yaitu satu provinsi dimana LAZ itu berada. ${ }^{7}$

Dalam Undang-Undang Nomor 23 Tahun 2011 tentang Pengelolaan Zakat LAZ dibentuk wajib berdasarkan izin Menteri atau pejabat yang ditunjuk oleh Menteri dan memiliki tujuan:

1) Meningkatkan efektivitas dan efisiensi pelayanan dalam pengelolaan zakat; dan

2) Meningkatkan pemanfaatan zakat untuk menciptakan kehidupan yang sejahtera untuk masyarakat serta mengurangi kemiskinan.

${ }^{5}$ Muhammad Hasan, Manajemen Zakat Model Pengelolaan yang Efektif (Yogyakarta: Idea Press Yogyakarta, 2011), 73.

${ }^{6}$ Nurul Huda, dkk., Zakat Perspektif Mikro-Makro Pendekatan Riset (Jakarta: Prenada Media Group, 2015), 11.

${ }^{7}$ Muhammad Hasan, Manajemen Zakat Model Pengelolaan yang Efektif, 46. 
Keberadaan lembaga amil zakat sebagai salah satu lembaga pengelola dana umat, saat ini mempunyai peranan penting dalam perkembang masyarakat. ${ }^{8}$ Peran LAZ sebagai lembaga pengelolaan yang saat ini sudah terlihat dalam kehidupan masyarakat adalah sebagai berikut:

1) Menjaga stabilitas sosial di masyarakat

Terkadang timbul rasa cemburu atau kesenjangan sosial yang terjadi dalam masyarakat, ini merupakan fenomenal sosial yang sudah tidak asing lagi. Hal ini jika tidak ditanggulangi akan berpotensi memberikan dampak negatif dalam kehidupan bermasyarakat. Dengan dilakukannya pengelolaan zakat oleh Lembaga Amil Zakat (LAZ) dan disalurkan secara merata, maka akan bisa mengurangi kecemburuan sosial, dendam dan rasa dongkol kaum yang lemah melihat kaum dengan ekonomi tinggi. ${ }^{9}$

2) Menyelesaikan permasalahan ekonomi dan menyejahterakan masyarakat

LAZ sebagai institusi yang mempunyai kewenangan menghimpun dana masyarkat secara legal formal, harus menjalankan tugasnya dengan semaksimal mungkin dalam mengelola potensi zakat yang ada. Potensi pengumpulan dana zakat dari umat Islam dapat menjadi solusi alternatif untuk didayagunakan dalam upaya menanggulangi kemiskian dan pemberdayaan ekonomi guna meningkatkan kesejahteraan masyarakat. ${ }^{10}$

\section{Strategi Pendistibusian Zakat Lembaga Amil Zakat (LAZ)}

Adapun strategi pendistribuasian zakat yang dapat diterapkan LAZ adalah sebagai berikut: ${ }^{11}$

1) Membagi areal penyaluran (pendistribusian/pendayagunaan)

Pembagian area penyaluran dilakukan agar tidak terjadi tumpang tindih dalam pendistribusian dan pendayagunaan. Tahapan ini dapat dilakukan dengan mengumpulkan perwakilan beberapa lembaga pengelola zakat dan melakukan pembagian wilayah. Misalnya pada pembagian areal mustahik untuk pendistribusian zakat dan pendayagunaan zakat.

2) Membagikan zakat kepada mustahik secara konsumtif

8 Didin Hafidhuddin (2019), “Peran Strategis Organisasi Zakat dalam Menguatkan Zakat di Dunia", Jurnal al-Infaq, 2(1), 1-4.

${ }^{9}$ Fakhrruddin, Figh dan Manajemen Zakat di Indonesia (Malang: UIN-Malang Press, 2008), 32.

${ }^{10}$ Fakhrruddin, Figh dan Manajemen Zakat di Indonesia, 253.

${ }^{11}$ Muhammad Hasan, Manajemen Zakat Model Pengelolaan yang Efektif, 90-93. 
a) Konsumtif Tradisional, yaitu zakat yang diberikan secara langsung kepada mustahik, seperti beras dan jagung, perbaikan rumah, dan lain-lain.

b) Konsumtif Kreatif, yakni zakat yang diberikan dalam bentuk lain, dengan harapan dapat bermanfaat lebih baik semisalnya beasiswa, peralatan sekolah, dan pakaian anak-anak yatim. ${ }^{12}$

3) Membagikan zakat kepada mustahik secara produktif

a) Produktif Konvensional yaitu dilakukan dengan memberikan zakat dalam bentuk barang produktif yang dapat digunakan mustahik untuk membuat usaha. Misalnya hewan ternak, mesin jahit, dan alat cukur.

b) Produktif Kreatif yaitu zakat diberikan kepada mustahik dalam bentuk pemberian modal usaha. Modal usaha ini berbentuk pengembangan usaha mustahik yang selanjutnya akan di awasi, diberi motivasi dan dibantu mengembangkan kemampuannya. ${ }^{13}$

\section{Program Pemberdayaan Ekonomi}

Program pemberdayaan ekonomi yang dilakukan oleh LAZ melalui pendayagunaan dana zakat merupakan solusi atas berbagai permasalahan yang dihadapi masyarakat. Program yang mengarah pada pemberdayaan ekonomi dapat mencakup bantuan pengembangan usaha, pemberdayaan petani dan pengrajin, paket pelatihan dan masih banyak lagi model pemberdayaan ekonomi lainnya.

Untuk menjadi seorang wirausaha dapat dilakukan melalui beberapa tahap kegiatan pembinaan, yaitu: motivasi, motivasi merupakan aktivitas perilaku yang menimbulkan usaha kepada seseorang untuk bekerja dan memenuhi kebutuhan hidupnya; pelatihan, latihan bertujuan untuk menyiapkan seseorang agar mempunyai kemampuan untuk mengerjakan pekerjaan; pemodalan, pemodalan sangat dibutuhkan dalam dunia usaha, karena modal memegang peranan penting dalam produksi.

Dalam menjalankan perannya dalam mengelola program pendayagunaan zakat, LAZ tentu didukung oleh sistem manajemen pengelolaan zakat, terutama dalam hal pelaksanaan fungsi-fungsi manajemen agar dapat terlaksana dengan baik. Berikut merupakan fungsi manajemen yang dapat diterapkan Lembaga Amil Zakat ${ }^{14}$ yaitu: pertama,

12 Ahmad Hasan Ridwan, Manajemen Baitul Mal wa Tamwil (Bandung: CV Pustaka Setia, 2013), 128.

13 Lailiyatun Nafiah (2015), "Pengaruh Pendayagunaan Zakat Produktif terhadap Kesejahteraan Mustahiq pada Program Ternak Bergulir Baznaz Kabupaten Gresik", Jurnal el-Qist, 5(1), 12-15.

${ }^{14}$ Ahmad Hasan Ridwan, Manajemen Baitul Mal wa Tamwil, 114-115. 
perencanaan yaitu tindakan yang telah dipersiapkkan untuk mendukung tercapainya tujuan sebuah kegiatan. Aspek perencanaan (planning) dalam organisasi zakat sebagai contoh meliputi SDM yang dibutuhkan dalam pengumpulan zakat, tenaga lapangan yang bertugas, menentukan waktu dan tempat, membuat target dana yang akan dihimpun dan disalurkan sesuai dengan ketentuan syariah. Kedua, pengorganisasian (organizing), pengorganisasian merujuk pada pembagian tugas dan tanggungjawab setiap pihak yang terlibat serta dapat memanfaatkan sarana dan prasarana yang ada di organisasi zakat. Ketiga, penggerakan (actuating), dalam fungsi penggerak diperlukan orang-orang yang mampu menggerakkan dan pihak-pihak yang memimpin serta membimbing orang yang digerakkan. Dapat berupa pemberian perintah, komunikasi dan koordinasi dalam proses pelaksanaan tugas organisasi. Keempat, pengawasan (controlling), pengawasan merupakan usaha pencocokan antara perencanaan dengan pelaksanaanya, meliputi tindakan pengamatan dan pemeriksaan serta pengendalian atas suatu kegiatan yang perlu diteliti dahulu.

\section{Metode Penelitian}

Dalam penelitian ini, peneliti memusatkan pembahasan pada program unggulan lembaga amil zakat Kudus dengan menggunakan jenis penelitian kualitatif, dimana peneliti sebagai instrument kunci. ${ }^{15}$ Penelitian ini merupakan penelitian lapangan (field research) bersifat kualitatif dan bercoak studi kasus. ${ }^{16}$ Penelitian studi kasus bukanlah sebuah pilihan metodologis, tetapi sebuah pilihan untuk mencari kasus yang perlu diteliti. ${ }^{17}$

Metode pengumpulan data dalam penelitian ini menggunakan tiga teknik, yaitu wawancara, observasi dan dokumentasi. Sumber data ${ }^{18}$ dalam penelitian ini berupa sumber data primer dan sekunder. Penelitian

15 Arif Furchan, Pengantar Metode Penelitian Kulitatif (Surabaya: Usaha Nasional, 1992), 21.

${ }_{16}$ Robert K. Yin, terj., Studi Kasus, Desain dan Metode (Jakarta: Rajawali Pers, 1997), 4.

${ }_{17}$ Menurut Robert K. Yin, studi kasus dibagai menjadi tiga, yaitu:

a. Explanatory StudiesYaitu peneliti memberikan keterangan-keterangan yang rinci dan penjelasan terhadap kasus yang diteliti.

b. Eksploratory StudiesYaitu penyelidikan secara mendalam misalnya peneliti yang terlibat langsung dengan obyek yang sedang diteliti.

c.Descriptive Case Studies Yaitu merupakan metode penelitian studi kasus yang fokus pada penguraian kasus yang sedang diteliti.

18 Data adalah segala keterangan (informasi) mengenai segala hal yang berkaitan dengan tujuan penelitian, maka tidak semua informasi bisa disebut data, tetapi hanya sebagian informasi yang berkaitan dengan penelitian merupakan data. Muhammad Idrus, Metode Penelitian Ilmu-Ilmu Sosial: Pendekatan Kaulitatif dan Kuantitaif (Yogyakarta; UII Press, 2007), 83. 
ini lebih pada usaha pengembangan teori atas dasar data yang telah dikumpulkan. Karenanya penelitian dimaksud merupakan grounded theory research. ${ }^{19}$ Sedang teknik analisis data yang digunakan dalam penelitian ini adalah teknik analisis data secara induktif.

Dalam tulisan ini, analisis data dilakukan secara kualitatif melalui tiga tahap, yaitu: reduksi data (data reduction), penyajian data (data display), serta penarikan kesimpulan dan verifikasi (conclution and verification). ${ }^{20}$ Reduksi data merupakan proses pemilihan dan pemusatan perhatian penelitian melalui seleksi yang ketat terhadap fokus yang akan dikaji lebih lanjut, penajaman fokus, pembuatan ringkasan hasil pengumpulan data, dan pengorganisasian data. ${ }^{21}$

\section{Hasil Penelitian}

\section{Analisis: Program Kampung Mandiri di LAZNAS Yatim Mandiri Cabang Kudus}

Program Kampung Mandiri yang dibentuk dan dibina oleh LAZNAS Yatim Mandiri Cabang Kudus merupakan jenis pendayagunaan dana zakat secara produktif, yaitu tergolong dalam pendayagunaan zakat produktif kreatif. Produktif kreatif adalah zakat yang diberikan kepada mustahik dalam bentuk pemberian modal usaha. Modal usaha ini berbentuk pengembangan usaha mustahik yang selanjutnya akan di awasi, diberi motivasi dan dibantu mengembangkan kemampuannya.

Program Kampung Mandiri LAZNAS Yatim Mandiri Cabang Kudus telah terlaksana di Desa Cangkring B Kecamatan Karanganyar Kabupaten Demak yang berbatasan langsung dengan Kabupaten Kudus. Program Kampung Mandiri telah membentuk usaha olahan bawang yaitu bawang goreng aneka rasa dengan branding "Bawang Goreng Guemez".

Program Kampung Mandiri dilakukan secara berkelompok dengan target sasarannya janda-janda miskin yang termasuk dalam mustahik. Modal yang diberikan oleh LAZNAS Yatim Mandiri Cabang Kudus berupa sejumlah uang yang diberikan untuk memenuhi kebutuhan usaha kelompok seperti alat-alat untuk memasak, dan bahan-bahan yang digunakan untuk produksi bawang goreng. Dana zakat berupa modal usaha tersebut diberikan tanpa adanya pengembalian.

Dibentuknya program pemberdayaan ekonomi Kampung Mandiri oleh LAZNAS Yatim Mandiri Cabang Kudus memiliki harapan agar

\footnotetext{
19 Sanapiah Faisal, Penelitian Kualitatif, Dasar-dasar dan Aplikasi (Malang: YA3, 1990), 108.

${ }^{20}$ J. Kirk, and M. Miller, Reliability and Validity in Qualitative Research (Beverly Hills, CA: Sage 1986), 30-34.

${ }^{21}$ Neong Muhadjir, Metode Penelitian (Yogyakarta : Sarasin, 2001), 360.
} 
janda-janda miskin dapat hidup mandiri dengan mendirikan usaha sendiri dan dapat membantu keluar dari permasalahan ekonominya.

LAZNAS Yatim Mandiri Cabang Kudus sebagai organisasi pengelola zakat memiliki fungsi selain sebagai perantara keuangan juga memiliki fungsi pemberdayaan. Program LAZNAS Yatim Mandiri Cabang Kudus melalui program pemberdayaan ekonomi Kampung Mandiri adalah sebagai berikut:

1) Perencanaan

LAZNAS Yatim Mandiri Cabang Kudus dalam program Kampung Mandiri juga diawali dari perencanaan yang matang agar hasilnya dapat sesuai dengan tujuan yang telah ditetapkan dan benarbenar dapat membantu mustahik. Adapun prosedur awal pembentukan Kampung Mandiri adalah sebagai berikut:

a) Sosialisasi ke beberapa desa, kriteria desa yang dipillih adalah ekonomi desa masih lemah dan desa memiliki potensi untuk didayagunakan sebagai usaha.

b) Pemilihan desa Kampung Mandiri

c) Meminta persetujuan Kepala Desa

d) Menentukan target sasaran, target sasaran dalam program Kampung Mandiri adalah janda-janda kurang mampu yang tinggal di desa yang terpilih.

e) Pelaksanaan kegiatan diawali dengan pertemuan rutin antara anggota Kampung Mandiri dengan LAZNAS Yatim Mandiri Cabang Kudus untuk pembinaan dan penentuan bidang usaha dan pelatihan.

2) Pengorganisasian

Pengorganisasian merujuk pada pembagian tugas dan tanggungjawab setiap pihak yang terlibat serta dapat memanfaatkan sarana dan prasarana yang ada di organiasasi zakat. ${ }^{22}$ Pengorganisasian dalam LAZNAS Yatim Mandiri terdiri atas bidang pengumpulan dana yang dilaksanakan oleh Zisco (Zakat, Infak, Sedekah Consultant) dan bidang penyaluran dana yang diatur oleh staf program.

Dalam program Kampung Mandiri yang terlibat dalam pengelolaannya adalah ketua beserta jajaran stafnya. Salah satu tugasnya adalah melakukan survei ke beberapa desa yang akan dibentuk program Kampung Mandiri. Dan untuk pengesahannya dilakukan oleh ketua LAZNAS Yatim Mandiri Cabang Kudus.

3) Pelaksanaan

\footnotetext{
${ }^{22}$ Muhammad dan Abubakar HM, Manajemen Organisasi Zakat Perspektif Pemberdayaan Umat dan Strategi Pembangunan Organisasi Pengelola Zakat (Malang: Madani, 2011), 60.
} 
Dalam penyaluran dananya LAZNAS Yatim Mandiri Cabang Kudus dibantu oleh seorang fasilitator yang telah dipercaya untuk mengelola keuangan. Dana tersebut diberikan secara langsung ke fasilitator, namun dalam pendistribusiannya ke Kampung Mandiri dilakukan secara bertahap sesuai kebutuhan, seperti untuk peralatan memasak dan bahan-bahan produksi.

Dana yang dianggarkan LAZNAS Yatim Mandiri Cabang Kudus sebesar Rp 128.590.000 digunakan sebagai modal usaha dan biaya lain-lain seperti pertemuan rutin, pelatihan skill dan bisnis. Selain itu dana yang diberikan juga digunakan untuk memberi upah harian kepada janda-janda yang hadir pada saat proses produksi. LAZNAS Yatim Mandiri Cabang Kudus memberikan dana tersebut secara hibah. Dengan demikian, tidak perlu adanya pengembalian dana kepada LAZNAS Yatim Mandiri dan keuntungan yang diperoleh menjadi milik anggota Kampung Mandiri.

4) Pengawasan

Pengawasan dilakukan dengan tujuan ingin mengetahui sudah sejauh mana kegiatan dilakukan, apakah hasilnya sesuai rencana atau belum. Pengawasan program Kampung Mandiri dilakukan oleh LAZNAS Yatim Mandiri dengan bekerjasama dengan seorang fasilitator, pengawasan tersebut meliputi:

a) Percaya kepada fasilitator, berjalannya program Kampung Mandiri, baik dari segi pengelolaan keuangan, proses produksi dan seluruh kegiatan telah dipercayakan kepada fasilitator sebagai seseorang yang mengatur jalannya program untuk mencapai tujuan.

b) Laporan fasilitator, fasilitator bertanggung jawab dan berkewajiban memberikan laporan kepada LAZNAS Yatim Mandiri Cabang Kudus. Berupa laporan kegiatan bulanan yang dilaksanakan oleh Kampung Mandiri serta laporan keuangan yang memperlihatkan perkembangan Kampung Mandiri mengalami kemajuan atau tidak.

c) Kunjungan, LAZNAS Yatim Mandiri Cabang Kudus berkunjung ke lokasi Kampung Mandiri, untuk melihat perkembangan secara langsung dan memberikan pembinaan serta sharing yang berkaitan dengan pelaksanaan kegiatan.

\section{Peran Program Kampung Mandiri LAZNAS Yatim Mandiri Cabang Kudus bagi Janda Miskin di Desa Cangkring B Karangayar Demak}

Program Kampung Mandiri yang dimiliki oleh LAZNAS Yatim Mandiri Cabang Kudus merupakan program pemberdayaan ekonomi, pembinaan keIslaman dan kepengasuhan. Program pemberdayaan 
ekonomi Kampung Mandiri dilakukan dengan membentuk kelompok usaha bersama dengan pendampingan profesional. Pendampingan dilakukan oleh seorang fasilitator yang memiliki ketrampilan dan pengetahuan dibidang usaha. Fasilitator tersebut dipilih dan dipercaya oleh LAZNAS Yatim Mandiri Cabang Kudus secara langsung.

Sasaran program Kampung Mandiri adalah janda-janda miskin. Tujuan program Kampung Mandiri adalah untuk meningkatkan kesejahteraan dan menjadikan janda-janda mampu mandiri. Untuk mengetahui sejauh mana keberhasilan yang telah dicapai LAZNAS Yatim Mandiri Cabang Kudus dalam melaksanakan program pemberdayaan ekonomi Kampung Mandiri selama ini dapat dilihat dari program Kampung Mandiri yang telah terlaksanakan di Desa Cangkring B, Karanganyar, Demak. Dari sini dapat diketahui sejauh mana peran Kampung Mandiri bagi janda-janda miskin di Desa Cangkring B dalam meningkatkan kesejahteraan keluarga janda tersebut melalui manfaat yang diperoleh dengan mengikuti program Kampung Mandiri. Hasil yang diperoleh dari mengikuti program Kampung Mandiri adalah:

1) Memberikan Ilmu Pengetahuan, dalam program Kampung Mandiri selain membentuk usaha, terdapat kegiatan pembinaan baik kewirausahaan maupun keIslaman bagi para janda. Pembinaan kewirausahaan dilakukan dengan memberikan motivasi-motivasi untuk mendirikan sebuah usaha. Sedangkan, pembinaan keIslaman sebagai bentuk pembinaan secara rohani dilakukan dengan mengadakan pengajian dan mendatangkan Ustadzah daerah setempat.

2) Menambah Ketrampilan, LAZNAS Yatim Mandiri Cabang Kudus memberikan pelatihan-pelatihan kepada janda-janda guna menambah ketrampilan mereka dalam berwirausaha. Pelatihan tersebut berupa pelatihan skill dan bisnis. Pelatihan skill merupakan kegiatan pelatihan untuk memproduksi produk-produk makanan dengan memanfaatkan potensi bahan-bahan yang ada di desa tersebut. Selain itu pelatihan bisnis lebih diutamakan pada pelatihan pemasaran, karena selain memiliki ketrampilan untuk memproduksi mereka juga harus bisa memasarkan produknya sendiri.

3) Menambah Penghasilan, Modal yang diberikan LAZNAS Yatim Mandiri Cabang Kudus untuk membentuk usaha juga digunakan untuk memberi upah kepada pada janda saat selesai melakukan produksi. Upah yang diterima setiap anggota Kampung Mandiri sama nilainya, karena dikerjakan secara kelompok maka upahnya dibagi rata. Pada Kampung Mandiri di Desa Cangkring B produk yang dihasilkan adalah bawang goreng, setiap mengolah $5 \mathrm{~kg}$ bawang 
diberikan upah $\mathrm{Rp}$ 30.000. Biasanya dalam sehari mampu mengolah sampai $40 \mathrm{~kg}$. Hasil upah tergantung dari kehadiran pada proses produksi, karena penghasilannya akan dibagikan secara rata kepada anggota kelompok yang melakukan kegiatan produksi. Jika seluruh anggota hadir, terdapat 20 orang sehingga diperkirakan penghasilan yang diperoleh kurang lebih $\mathrm{Rp} 60.000$ dalam sehari. Namun kegiatan produksi hanya dilakukan seminggu sekali atau saat ada pesanan.

\section{Faktor Pendukung dan Penghambat Pelaksanaan Program Kampung Mandiri di Desa Cangkring B Karanganyar Demak}

1) Faktor Pendukung

a) Faktor Internal

(1) Adanya pemodalan, modal atau keuangan merupakan faktor penunjang dan pendukung keberhasilan dalam berwirausha. Keuangan digunakan untuk modal usaha seperti untuk biaya produksi, pembelian bahan baku, promosi dan pemasaran serta gaji. ${ }^{23}$ Dalam pelaksanaan program pemberdayaan ekonomi Kampung Mandiri, modal yang diberikan kepada anggota kelompok Kampung Mandiri sudah disediakan oleh LAZNAS Yatim Mandiri Cabang Kudus untuk memenuhi segala kebutuhan dalam pelaksanaan program Kampung Mandiri.

b) Faktor Eksternal

(1) Adanya fasilitas, fasilitas khususnya dari pemerintah desa sangat diperlukan. Fasilitas yang diperlukan itu berupa bantuan kemudahan dalam mengurus perizinan, bantuan dalam penyebaran informasi dan sebagainya. ${ }^{24}$ Dalam membentuk program Kampung Mandiri, Kepala Desa Cangkring memberikan kemudahan dengan mengizinkan serta medukung program Kampung Mandiri. Selain memberi dukungan dalam bentuk izin pelaksanaan program. Dari pihak desa juga turut serta memberikan bantuan berupa alat-alat untuk mendukung berkembangnya program Kampung Mandiri. Selain itu program Kampung Mandiri LAZNAS Yatim Mandiri Cabang Kudus juga mendapatkan fasilitas tempat yang merupakan hibah dari seseorang yang juga merupakan warga Desa Cangkring B. Tempat ini dihibahkan untuk menjadi wakaf

23 Abdullah Muin Sibuea dan Dadang Mulyana, Pengantar Kewirausahaan Dalam Meningkatkan Pemahaman Kewirausahaan, (Medan: Perdana Publishing, 2018), 119, http://digilib.citapustaka.com/index.php?p=fstream-pdf\&fid=9\&bid=23.

24 Abdullah Muin Sibuea dan Dadang Mulyana, Pengantar Kewirausahaan Dalam Meningkatkan Pemahaman Kewirausahaan, 122-123. 
produktif dan dijadikan sebagai tempat produksi serta perkumpulan anggota Kampung Mandiri.

(2) Adanya bahan baku. Bahan baku merupakan barang-barang yang diperoleh untuk digunakan dalam proses produksi. Beberapa bahan baku diperoleh secara langsung dari sumbersumber alam, bahan baku juga dapat diperoleh dari perusahaan lain. ${ }^{25}$ Desa Cangkring B merupakan desa yang mayoritas penduduknya adalah petani. Sehingga bahan yang diperlukan untuk produksi tersedia dan tidak ada permasalahan untuk mencari bahan produksi. LAZNAS Yatim Mandiri Cabang Kudus menghendaki agar program Kampung Mandiri dapat memanfaatkan potensi dari desa sendiri.

2) Faktor Penghambat

a) Faktor Internal

(1) Lemahnya usaha pemasaran (promosi), salah satu kelemahan usaha terutama usaha dalam skala kecil adalah tidak memiliki pengetahuan tentang strategi pemasaran produk dan jasa. ${ }^{26}$ Proses pemasaran produk bawang goreng Kampung Mandiri kurang optimal, lebih banyak dibantu oleh Fasilitator. Sedangkan anggota kelompoknya sendiri masih kurang percaya diri dalam memasarkan produknya. Selain itu kurangnya pengetahuan tentang pemasaran menyebabkan terhambatnya proses pemasaran produk. Dan juga dikarenakan sebagian besar anggotanya ibu-ibu jadi untuk pemanfaatan sosial media agar produknya lebih dikenal luas masih kurang. Sehingga pemasaran kurang optimal dan saat ini masih terbatas pada daerah sendiri dan daerah sekitar Desa Cangkring B.

(2) Kurangnya Sumber Daya Manusia (SDM), SDM merupakan aset paling berharga dalam usaha, tanpa manusia maka sumber daya perusahaan tidak akan dapat menghasilkan laba atau menambah nilainya sendiri. ${ }^{27}$ Proses pelaksanaan produksi yang belum maksimal disebabkan ada sebagian janda yang bekerja.

25 Rusdiana, Manajemen Operasi (Bandung: CV. Pustaka Setia, 2014), 368, http://digilib.uinsgd.ac.id/8788/1/Buku\%20Manajemen\%200perasi.pdf.

${ }^{26}$ Rusydi Ananda dan Tien Rafida, Pengantar Kewirausahaan Rekayasa Akademik Melahirkan Enterpreneurship, (Medan: Perdana Publishing, 2016), 212, http://repository.uinsu.ac.id/3581/1/2.\%20BUKU\%20PENGANTAR\%20KEWIRAUSAHA AN.pdf.

27 Taufiqurokhman, Mengenal Manajemen Sumber Daya Manusia (Jakarta: Fakultas Ilmu Sosial dan Ilmu Politik Universitas Prof. Dr. Moestopo Beragama, 2009), 1, https://moestopo.ac.id/wp-content/uploads/2016/08/MENGENAL-SUMBER-DAYAMANUSIA-Oleh-Dr.-Taufiqurokhman,-M.Si_.pdf. 
Sehingga saat proses produksi ada anggota yang berhalangan masuk karena ada pekerjaan. Kebanyakan hal ini terjadi pada musim tanam, beberapa janda ini bekerja untuk menanam disawah, sehingga proses produksi dikesampingkan dan produksipun menjadi kurang maksimal karena jumlah anggota yang turut serta hanya sedikit.

(3) Kurangnya manajemen waktu, manajemen waktu terkait dengan aktivitas untuk memanfaatkan waktu yang tersedia dan potensi-potensi yang tertanam dalam diri guna mewujudkan tujuan-tujuan penting yang ingin dicapai. ${ }^{28} \mathrm{Kampung}$ Mandiri memiliki anggota yaitu para janda. Terkandang kendala terjadi pada saat adanya perkumpulan anggota, sulitnya mengelompokkan janda-jandanya agar berkumpul semua dalam satu waktu. Ada beberapa anggota yang beralasan tidak bisa hadir.

b) Faktor Eksternal

(1) Iklim (musim), produksi bawang merah sangat dipengaruhi oleh iklim karena bawang merah sangat peka terhadap hujan dan kekeringan. Kampung Mandiri yang memiliki usaha dalam bidang olahan bawang goreng memiliki kendala pada bawang, walaupun desa Cangkring B memproduksi bawang sendiri namun jika iklim di daerah desa Cangkring B tidak menentu maka produksi bawang akan terhambat dan kadang juga hasilnya tidak bagus atau kualitasnya buruk. Sehingga harus memasok bawang dari tempat lain.

\section{Simpulan}

Berdasarkan pembahasan diatas maka dapat disimpulkan bahwa program Kampung Mandiri yang dibentuk oleh LAZNAS Yatim Mandiri Cabang Kudus merupakan jenis pendayagunaan zakat secara produktif dan tergolong pendayagunaan zakat produktif kreatif dalam bidang pemberdayaan ekonomi. Program Kampung Mandiri LAZNAS Yatim Mandiri Cabang Kudus telah terlaksana di Desa Cangkring B Kecamatan Karanganyar Kabupaten Demak yang membentuk kelompok usaha bersama dengan janda-janda miskin sebagai anggotanya berjumlah 20 orang. Usaha yang dijalankan dalam program Kampung Mandiri binaan LAZNAS Yatim Mandiri Cabang Kudus yaitu olahan bawang goreng aneka rasa dengan branding "Bawang Goreng Guemez".

\footnotetext{
${ }^{28}$ Rusydi Ananda dan Tien Rafida, Pengantar Kewirausahaan Rekayasa Akademik Melahirkan Enterpreneurship, 203.
} 
Program LAZNAS Yatim Mandiri Cabang Kudus dalam pembentukan Kampung Mandiri yaitu pertama, perencanaan dalam perencanaan LAZNAS Yatim Mandiri Cabang Kudus bertugas merencanakan tindakan-tindakan untuk mencapai tujuan dimulai dari awal pembentukan program hingga pelaksanaan programnya. Kedua, penyaluran dana disini LAZNAS Yatim Mandiri Cabang Kudus menyalurkan dananya berupa uang tunai melalui fasilitator program Kampung Mandiri untuk digunakan sebagai modal serta sarana dan prasarana program, disalurkan secara bertahap sesuai kebutuhan. Ketiga, pengawasan dalam pengawasannya LAZNAS Yatim Mandiri Cabang Kudus dilakukan dengan dua cara yaitu melalui laporan fasilitator program Kampung Mandiri dan kunjungan secara langsung disertain dengan pembinaan.

\section{Daftar Pustaka}

Ananda, Rusydi dan Tien Rafida. Pengantar Kewirausahaan Rekayasa Akademik Melahirkan Enterpreneurship. Medan: Perdana Publishing, 2016.

http://repository.uinsu.ac.id/3581/1/2.\%20BUKU\%20PENGANTAR \%20KEWIRAUSAHAAN.pdf.

Fakhrruddin. Figh dan Manajemen Zakat di Indonesia. Malang: UIN-Malang Press, 2008.

Hafidhuddin, Didin. (2019), "Peran Strategis Organisasi Zakat dalam Menguatkan Zakat di Dunia", Jurnal al-Infaq, 2(1).

Hasan, Muhammad. Manajemen Zakat Model Pengelolaan yang Efektif . Yogyakarta: Idea Press Yogyakarta, 2011.

Huda, Nurul, Novarini, Yosi Mardoni, dan Citra Permatasari. Zakat Perspektif Mikro-Makro Pendekatan Riset. Jakarta: Prenada Media Group, 2015.

Mardani. Hukum Islam: Zakat Infak Sedekah dan Wakaf (Konsep Islam Mengentaskan Kemiskinan dan Menyejahterakan Umat). Bandung: PT Citra Aditya Bakti, 2016.

Muhammad dan Abubakar HM. Manajemen Organisasi Zakat Perspektif Pemberdayaan Umat dan Strategi Pembangunan Organisasi Pengelola Zakat. Malang: Madani, 2011.

Nafiah, Lailiyatun. (2015), “Pengaruh Pendayagunaan Zakat Produktif terhadap Kesejahteraan Mustahiq pada Program Ternak Bergulir Baznaz Kabupaten Gresik", Jurnal el-Qist, 5(1).

Ridwan, Ahmad Hasan. Manajemen Baitul Mal wa Tamwil. Bandung: CV Pustaka Setia, 2013. 
Rusdiana. Manajemen Operasi. Bandung: CV. Pustaka Setia, 2014. http://digilib.uinsgd.ac.id/8788/1/Buku\%20Manajemen\%200perasi.p df.

Sibuea, Abdullah Muin dan Dadang Mulyana. Pengantar Kewirausahaan Dalam Meningkatkan Pemahaman Kewirausahaan. Medan: Perdana Publishing, 2018. http://digilib.citapustaka.com/index.php?p=fstreampdf\&fid=9\&bid=23.

Syahriza, Mulkan; Pangeran Harahap; Zainul Fuad (2019), "Analisis Efektifitas Distribusi Zakat Produktif dalam Meningkatkan Kesejahteraan Mustahik (Studi Kantor Cabang Rumah Zakat Sumatera Utara)", at-Tawassuth, IV (1).

Taufiqurokhman. Mengenal Manajemen Sumber Daya Manusia. Jakarta: Fakultas Ilmu Sosial dan Ilmu Politik Universitas Prof. Dr. Moestopo Beragama, 2009. https://moestopo.ac.id/wpcontent/uploads/2016/08/MENGENAL-SUMBER-DAYAMANUSIA-Oleh-Dr.-Taufiqurokhman,-M.Si_.pdf.

Undang-Undang Republik Indonesia, “23 Tahun 2011, Pengelolaan Zakat," 25 November 2011

Wibisono, Yusuf. Mengelola Zakat Indonesia DIskursus Pengelolaan Zakat Nasional dari Rezim Undang-Undang Nomor 38 Tahun 1999 ke Rezim Undang-Undang Nomor 23 Tahun 2011. Jakarta: Prenadamedia Group, 2015. 